\title{
Public Auditors' Professionalization at International Level
}

\author{
Iliodor Tiberiu Plesa \\ tiberiu.plesa@gmail.com \\ Valahia University of Targoviste, Romania
}

\begin{abstract}
The argument for professionalization in any field is simple: it connects practitioners from a particular field and aims to ensure that the users of professional services in that field can be confident that they are offered to the appropriate standards. This article aims to analyze the concept of "professionalization of public sector auditors", a new concept recently introduced at the level of the international public audit community. Also, during the paper, the different practices used by the supreme audit institutions regarding the professionalization of their specialized personnel (public auditors) and the INTOSAI proposals on this issue will be addressed.
\end{abstract}

Keywords: professionalization, public audit, supreme audit institution, INTOSAI

\section{Introduction}

The term "professionalization" has several definitions. One of the definitions, found in Explanatory Dictionary of Romanian Language ${ }^{83}$, presents the professionalization as "the action to professionalize and its outcome "," to make or to acquire a professional character", "to make to become or to become a profession".

The professionalization has two facets. On the one hand, it refers to the improvement of status and, on the other hand, refers to improving the ability of members to enhance the services provided. This process of professionalization ${ }^{84}$ involves the development of skills, norms and values necessary to become part of a professional group. Individuals taking part in this process develop background knowledge and skills that enable them to function later as professionals in the field.

In other words, the professionalization involves a process of education, training and other specific activities in order to transform an individual into a professional and, to the same extent, the professionalization describes the social processes through which occupation becomes a profession ${ }^{85}$.

On the other hand, there are differences between occupation and profession. Thus, with regard to occupation, the profession has the following characteristics ${ }^{86}$ :

$>$ The need to obtain qualifications, in order to practice the profession, qualifications that are often obtained through exams;

The existence of professional associations;

$>$ The existence of an ethical code of the profession;

The interests of the client are protected;

Services are offered to the public that is recognizing and accepting them.

Practically, through professionalization, certain exclusive rights are obtained in terms of practicing an occupation and, in this way, the control over the access of individuals to that occupation is obtained, a reason for which the professionalization has become synonymous with prestige.

\footnotetext{
83 Dicționarul explicativ al limbii române (1996)

${ }^{84}$ F.J. Levine, Professionalization of Social and Behavioural Scientists: United States, International Encyclopedia of the Social \& Behavioural Sciences, pp. 12146-12154 (Science Direct https://doi.org/10.1016/B0-08-043076-7/00050-4)

85 National Research Council. 2013. Professionalizing the Nation's Cybersecurity Workforce?: Criteria for Decision-Making. Washington, DC: The National Academies Press. https://doi.org/10.17226/18446.

${ }^{86}$ Reynolds, M.A. (2000). Professionalism, Ethical Codes and the Internal Auditor: A Moral Argument. Journal of Business Ethics, 24.
} 
Andrew Abbott ${ }^{87}$ mentions the following types of relationships that can be found between professions and their jurisdictions (the areas on which these professions operate):

$>$ A complete jurisdiction, whereby a profession holds exclusivity in a particular field, without competition from others;

$>$ A subordinate jurisdiction, whereby a profession considered superior from the hierarchical point of view controls the activity of a subordinate profession;

$>$ An intellectual jurisdiction, whereby the superior profession has control over access to knowledge and allows other professional groups to operate without major restrictions

$>$ An advisory jurisdictions, whereby a profession has the right to interpret and modify the work of another profession;

$>$ A divided jurisdiction, whereby a jurisdiction is divided between two professions.

Starting from Abbott's classification, we will continue to look at professionalization from the perspective of internal audit and external public audit.

\section{The professionalization in internal audit}

In the field of internal audit, professionalization is carried out through the Institute of Internal Auditors - IIA, an institute created in 1941, which has developed a system of standards for internal audit, has designed exams and a certification system for internal auditors at the request of practitioners in this field, which signaled the lack of an official program for the professional training of internal auditors.

Nowadays, the Institute of Internal Audit offers internal audit certification ${ }^{88}$ through its certification system. The certification system offers several types of specialization, including Certified Internal Auditor (CIA Certification), Certification in Risk Management Assurance (CRMA Certification), Qualification in Internal Audit Leadership (QIAL) and Certification for Environmental, Health \& Safety Auditors (CPEA-CPSA).

All these certificates are important, most of the organizations setting as requirement for hiring internal auditors to hold such a certificate, but not all require certificates from IIA, they also accept other types of certificates issued by other institutions.

As I mentioned previously with regard to the characteristics of a profession, the Institute of Internal Auditors developed the Code of Ethics for Internal Auditor ${ }^{89}$ s, which contains a set of principles relating to the ethical and professional conduct of internal auditors and organizations in conducting internal audit work, in order to promote an ethical culture within the profession of internal audit.

As regarding the organization of internal audit in our country ${ }^{90}$, this includes the Public Internal Audit Committee, the Central Harmonization Unit for Public Internal Audit, the Internal Audit Committees and the Internal Audit Offices.

In Romania, as regards internal audit, the internal auditors are certified by the Ministry of Public Finance, through the Audit Commission of Internal Auditors in the Public Sector and Individuals. Also, the Internal Audit Charter, which defines the role and objectives of internal audit and also the methodology and rules of conduct governing the internal audit activity have been developed.

\footnotetext{
87 Abbott, A. (1988). The system of professions. An Essay on The Division of Expert Labor. Chicago: University of Chicago Press.

88 https:// na.theiia.org/certification/Pages/Certification.aspx , accesat la 01.06.2019

89 https://global.theiia.org/standards-guidance/mandatory-guidance/Pages/Code-of-Ethics.aspx, accesat la 01.06.2019

90 Strategia dezvoltării auditului public intern pentru 2018-2020 disponibilă la

http://www.mfinante.gov.ro/pagina.html?categoriebunuri=strategia-cfpi\&pagina=domenii\&menu=Ucaapi , accesat la 02.06.2019
} 
Also, at national level, in order to strengthen the role of internal audit, the Association of Internal Auditors in Romania ${ }^{91}$ (AAIR) was established in order to increase the prestige of the internal auditor profession, as well as to promote and to develop the internal audit practice.

\section{The professionalization in public audit. International trends}

At the level of the international public audit community, the idea of professionalization originated for the first time in 2014, when a research on certification and other key aspects of professional development was considered within INTOSAI (the International Organization of Supreme Audit Institutions). The results of this research have led to the development of a "White Paper on Professional Development" in INTOSAI, with a series of recommendations, being developed the INTOSAI Operational Working Group on Auditor Professionalization (TFIAP).

In 2019, the INTOSAI Capacity Building Committee developed a "Guide on Professionalization pathways ${ }^{\prime \prime 2}$, a guideline that provides guidance to supreme audit institutions on the professionalization of public auditors with regard to the:

$>$ Development of a competence framework at the institutional level, based on the core principles of the INTOSAI competence framework, but adapted to the circumstances in which the supreme audit institution works (mandate, attributions, functioning, etc.);

$>$ Impact of the Supreme Audit Institution's competence framework on human resources processes;

$>$ Available options for reorganizing specific ways of professional development at INTOSAI level, based on responses from the supreme audit institutions and their research in this field;

$>$ Elements that a supreme audit institution will have to consider when it comes to developing its own professional development strategy.

The first part of the Guide analyzes the process of selection of professional qualifications, and the second part addresses the process of implementation of professional qualifications.

Taking into account the diversity of the supreme audit institutions, which is based both on differences of the model of supreme audit institution (Westminster model, Collegial model or Jurisdictional model) and the differences regarding the national specificity, organization and functioning, this Guide specifies it is clear that the supreme audit institutions need to adapt their competence frameworks according to the requirements imposed by the differences described above.

The idea of certification of public auditors first appeared in Finland ${ }^{93}$ at the end of the 1980s, being introduced in 1989 the certification of "Chartered Public Finance Auditors (CPFA)" by the Finnish Ministry of Education.

The vision of AFROSAI-E (Organization of Supreme Audit Institutions in Africa using English) on professionalization refers to a certification system ${ }^{94}$ for auditors, while adhering to the concept of a global profession with a local solution that recognizes the diversity of Supreme Audit Institutions within the INTOSAI community.

International practices regarding the professionalization of public auditors are sundries ${ }^{95}$.

The UK Supreme Audit Institution (National Audit Office - NAO) uses the UK's Financial Reporting Council (FRC) statements and, with regard to its staff, the institution has adopted a set of competencies for both audit and non-audit staff, focusing on staff behavior. As

\footnotetext{
91 http:/ / www.aair.ro/index.php?option=com_content\&view=article\&id=16\&Itemid=134\&lang=ro , accesat la 02.06 .2019 
far as professional training is concerned, within this Supreme Audit Institution there are organized courses for the specialized staff, which are delivered both by their own trainers and by external trainers.

The French Court of Accounts, a supreme audit institution with jurisdictional functions, differs from the other supreme audit institutions in that, in addition to the usual audit work, it has the capacity to hold accountable those who fail to fulfill their obligations legal powers conferred by the function it exercises through a process that takes place at the French Court of Accounts. At the level of this institution, there is no set of rules on individual competences that underpin the professionalization of its staff. However, the French law provides that the magistrates, the auditors, the experts and the external rapporteurs must abide by the professional standards established by the First President of the French Court of Accounts. In order to add a high level of professionalism, the auditors of the French Court of Accounts have to swear an oath as magistrates. On the other hand, most of the magistrates are graduates of the École Nationale d'Administration, being recruited in the French Court of Accounts after four years as beginner auditors and then becoming senior auditors after 12 years.

In Georgia, the Supreme Audit Institution uses a competency framework that is in line with the provisions of the Georgian Civil Service Law, plus some requirements based on the needs and best practices identified at the supreme audit institution. Regarding the training, the Court of Accounts of Georgia provides most of its training programs through the Public Audit Institute, a legal personality entity set up under the Georgian Court of Accounts organization and operation law.

Other examples of certification systems for public auditors are found at the level of the supreme audit institutions in the United States, France, Austria and Japan ${ }^{96}$.

The Supreme Audit Institution in Japan, as regards its competence framework for its staff, distinguishes three categories of competences, namely ethics skills, knowledge skills and professional skills. In most cases, the Court of Accounts of Japan recruits the staff it needs from those who passed the exam passed to the National Authority for Personnel, and then professionally prepares them to acquire the necessary skills for becoming a good public auditor.

In Netherlands, the supreme audit institution uses a personalized competence framework, where competence areas are described as personal results. This competence framework does not distinguish between types of audit and does not refer to international auditing standards for the public sector (ISSAI). As regards newly recruited auditors, the Dutch Court of Auditors has implemented an initial training program for them, which takes place within the first 12 months of their recruitment in Dutch Supreme Audit Institution. For basic staff, the Dutch Court of Auditors offers a wide range of professional training courses, including basic knowledge and skills in the field of public audit, advanced knowledge and other professional tools.

As a general conclusion, the supreme audit institutions recognize the qualifications of their staff at international level within professional organizations and encourage them to obtain these.

\section{Conclusions}

The professionalization is an extremely important element in a profession. It provides confidence in the quality of the services offered by the profession.

In many areas, we find this professional component, often in the form of organizations that offer certification in the areas they regulate.

Regarding the audit, at international level there are certification bodies for internal audit but also for external audit, which provides professionalism to these professions, through the higher training they provide to those who obtain the certificates issued by them.

96 http://www.intosaicommunity.net/user/newsdetails/28, accesat la 06.04.2019 
At the INTOSAI level, there is still no mandatory regulatory framework for public auditors, but there is a Guide designated for Supreme Audit Institutions in this field. The guide is not binding, but it translates into its content the best-practices identified internationally, based on the studies and observations made by the supreme audit institutions. It should also be noted that those proficiency frameworks developed by international professional organizations cannot fully meet the needs of the supreme audit institutions, due to the specific nature of their activities, but they are a starting point for INTOSAI.

The analysis of identifying practices at the level of the supreme audit institutions revealed that they have differently developed their practices, as regards the professionalism of their specialized staff. Thus, some of them preferred to develop and deliver training programs using their own resources (the case of Georgia), others preferred to work in partnership with national professional organizations (UK) and others preferred to work together in regional organizations (AFROSAI-E case).

Regardless of the approach chosen, it is extremely important for the supreme audit institutions to implement a competence framework, given that this framework confers professionalism and confidence to the stakeholders interested in the work of these institutions.

\section{References}

1. Dictionarul explicativ al limbii române (1996)

2. F.J. Levine, Professionalization of Social and Behavioural Scientists: United States, International Encyclopedia of the Social \& Behavioural Sciences, pp. 12146-12154 (Science Direct bttps://doi.org/10.1016/B0-08-043076-7/00050-4)

3. National Research Council. 2013. Professionalizing the Nation's Cybersecurity Workforce?: Criteria for Decision-Making. W ashington, DC: The National Academies Press. https:/ / doi.org/10.17226/18446.

4. Reynolds, M.A. (2000). Professionalism, Ethical Codes and the Internal Auditor: A Moral Argument. Journal of Business Ethics, 24.

5. Abbott, A. (1988). The system of professions. An Essay on The Division of Expert Labor. Chicago: University of Chicago Press.

6. https:/ / na.theiïa.org/certification/Pages/Certification.aspx , accesat la 01.06.2019

7. https://global.theiia.org/standards-guidance/mandatory-guidance/Pages/Code-of-Ethics.aspx, accesat la 01.06 .2019

8. Strategia dezvoltării auditului public intern pentru 2018-2020, disponibilă la

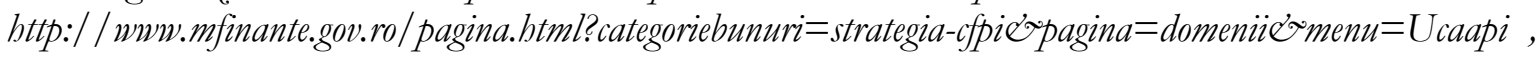
accesat la 02.06.2019

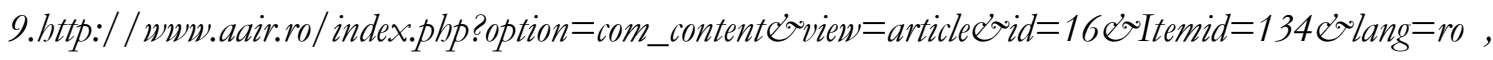
accesat la 02.06.2019

10. Developing pathways For the Professional Development of Auditors in a Supreme Audit Institution (SAI). Utilising the INTOS AI competency framework to develop public sector audit professionals in the most contextappropriate way, disponibil la https:/ / wmw.intosaicbcorg/wp-content/ uploads/2019/02/Guide-onprofessionalisation-pathways-11.pdf, accesat la 02.06.2019

11.https:// www.intosaicbc.org/wp-content/ uploads/2019/05/Draft-final-report-sent-to-GIZ_27-11-2018.pdf , accesat la 02.06.2019

12. Kim P. Jeppesen, Establishing a Certified Public Sector Auditor qualification: The Danish case and its implications, Copenhagen Bussiness School, p. 4, disponibil la

bttps://openarchive.cbs.dk/ bitstream/ handle/10398/6745/wp_2008-01.pdf?sequence=1, accesat la 06.04.2019

13. bttp:// www.intosaicommunity.net/user/newsdetails/28, accesat la 06.04.2019 